\title{
A Bromeliad-Inhabiting Mosquito Wyeomyia vanduzeei Dyar and Knab 1906 (Insecta: Diptera: Culicidae)'
}

\author{
Catherine Lippi and Eva A. Buckner ${ }^{2}$
}

\section{Introduction}

Wyeomyia vanduzeei (Figure 1) is a mosquito species native to Florida that utilizes bromeliads for oviposition and pre-adult development. In general, Wyeomyia adults are delicate, short-lived, and do not disperse far from the bromeliads they inhabit as immatures. Immature Wyeomyia vanduzeei can be found in multiple bromeliad species native to Florida but are most closely associated with the Florida native Tillandsia utriculata, commonly known as the spreading airplant or giant airplant (Figure 2), which is used for egg-laying and larval rearing. For more information on the spreading airplant, see http://edis.ifas.ufl.edu/ uw205. In addition to native bromeliads, immature Wyeomyia vanduzeei can also be found in the water-filled tanks and leaf axils of the many exotic ornamental bromeliads (Figure 3) that have been imported into Florida (O'Meara et. al 2003, Frank and Fish 2008). Although not known to transmit pathogens that cause diseases to humans, Wyeomyia vanduzeei can be an annoying daytime biter, especially in southern Florida where exotic bromeliads are commonly used as landscape plants.

\section{Distribution}

Wyeomyia vanduzeei can be found in the contiguous United States, Cuba, the Cayman Islands, and Jamaica (Figure 4; Frank and Fish 2008). In the contiguous United States, Wyeomyia vanduzeei is native only to counties in central and southern Florida that generally do not experience hard freezes in winter (Figure 5; Darsie and Morris 2003, O'Meara et al. 2003) However, due to the ornamental bromeliad industry, Wyeomyia vanduzeei can also be found outside its native range in exotic bromeliads in greenhouses (Figure 6) and in and around homes (Frank et. al 1988).

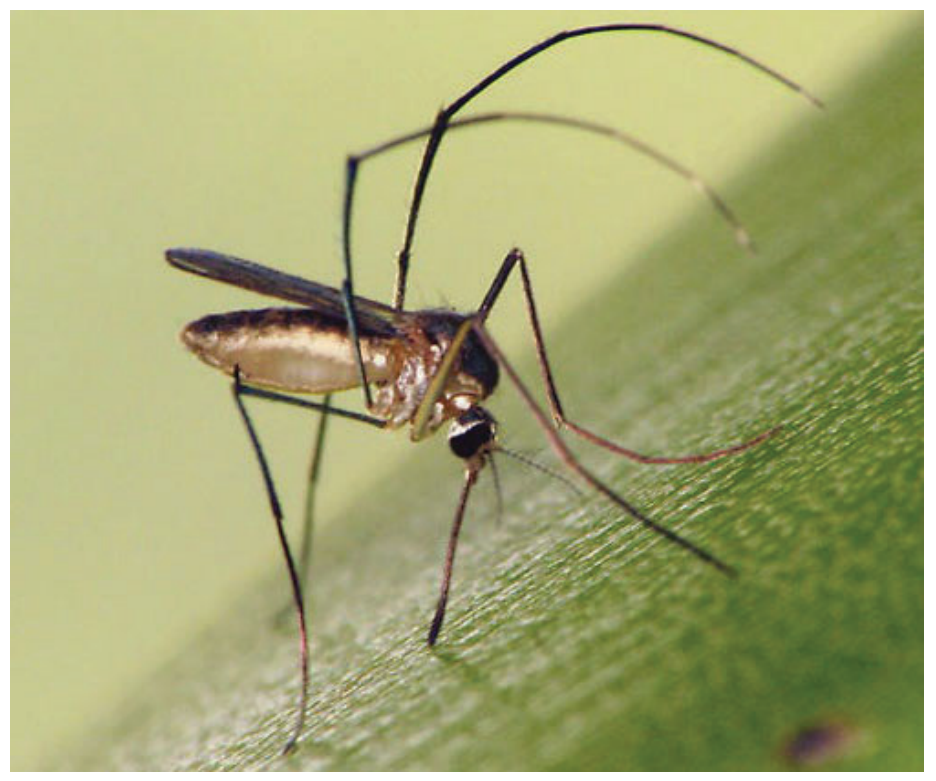

Figure 1. Adult Wyeomyia vanduzeei female.

Credits: Sean McCann (smmccann@sfu.ca), Simon Fraser University

1. This document is EENY-747, one of a series of the Entomology and Nematology Department, UF/IFAS Extension. Original publication date April 2020. Visit the EDIS website at https://edis.ifas.ufl.edu for the currently supported version of this publication. This document is also available on the Featured Creatures website at http://entnemdept.ufl.edu/creatures/.

2. Catherine Lippi; and Eva A. Buckner, Florida Medical Entomology Lab, Entomology and Nematology Department; UF/IFAS Extension, Gainesville, FL 32611.

The Institute of Food and Agricultural Sciences (IFAS) is an Equal Opportunity Institution authorized to provide research, educational information and other services

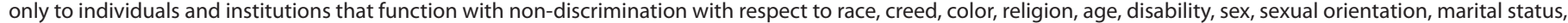

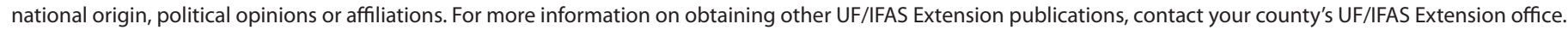
U.S. Department of Agriculture, UF/IFAS Extension Service, University of Florida, IFAS, Florida A \& M University Cooperative Extension Program, and Boards of County Commissioners Cooperating. Nick T. Place, dean for UF/IFAS Extension. 


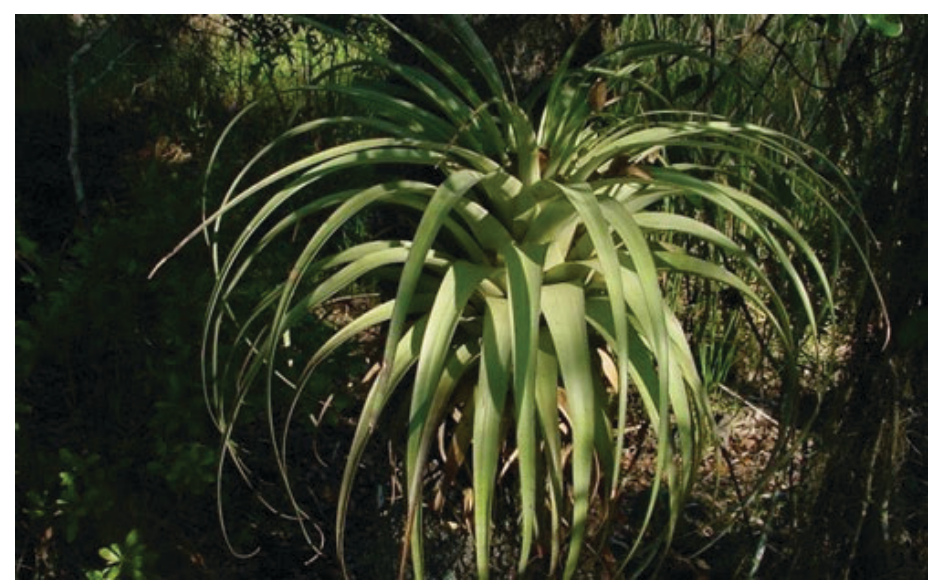

Figure 2. The spreading airplant, Tillandsia utriculata, is a bromeliad native to Florida and the preferred native nursery plant for Wyeomyia vanduzeei.

Credits: Jimmy Yawn (sfbcp@SaveBromeliads.com), Save Florida's Bromeliads Conservation Project

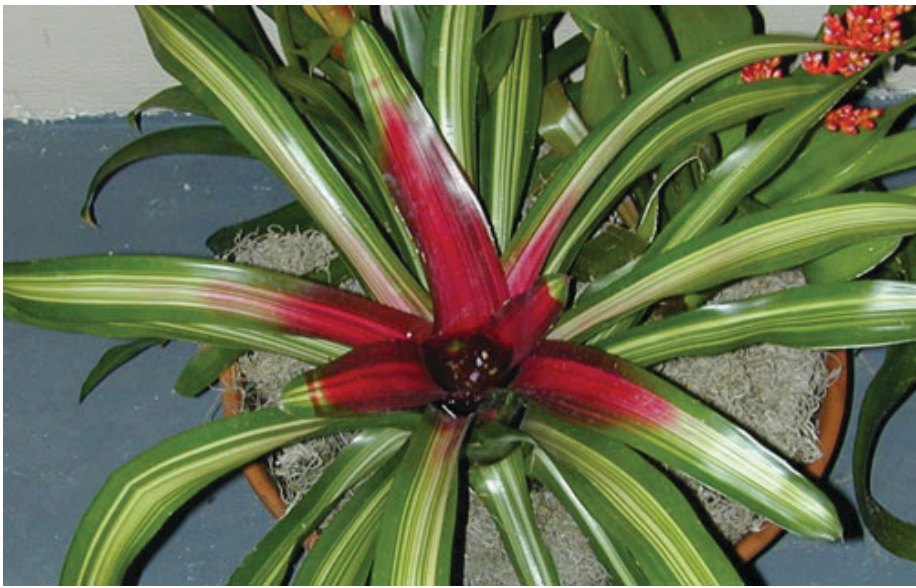

Figure 3. Exotic bromeliad plant with water-filled tank and leaf axils, the habitat for immature Wyeomyia vanduzeei.

Credits: James Newman (newmans@ufl.edu), University of Florida

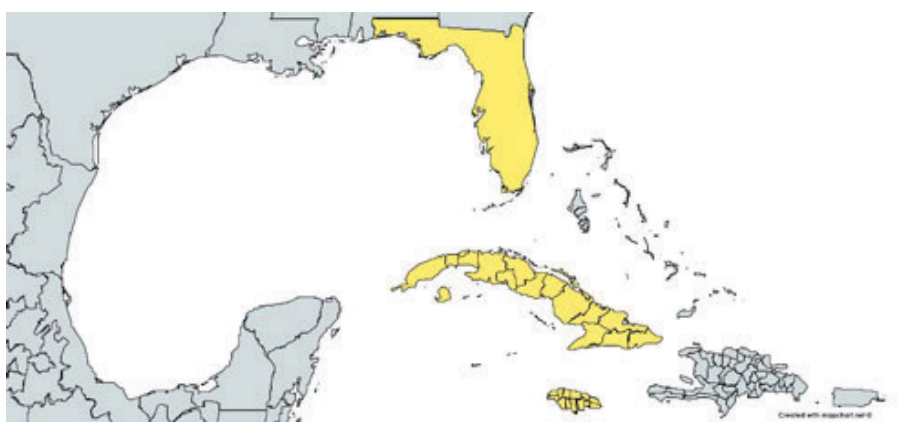

Figure 4. Distribution of Wyeomyia vanduzeei.

Credits: Eva A. Buckner, UF/IFAS

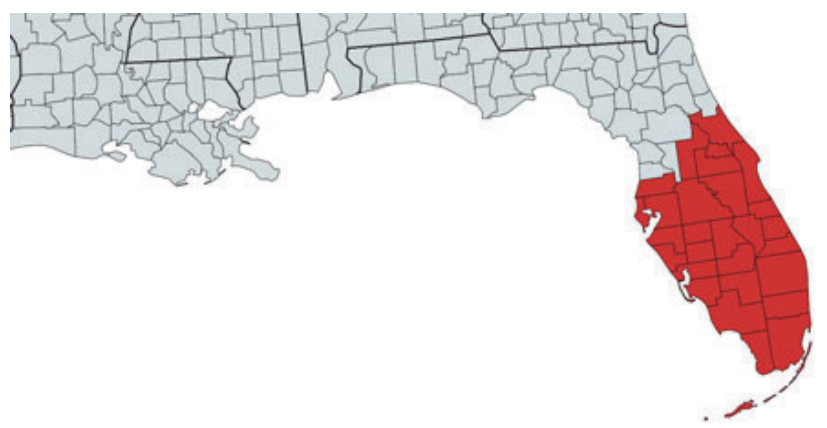

Figure 5. Generalized native distribution of Wyeomyia vanduzeei in Florida based on Darsie and Morris 2003, O'Meara et al. 2003, and

Darsie and Ward 2005.

Credits: Eva A. Buckner, UF/IFAS

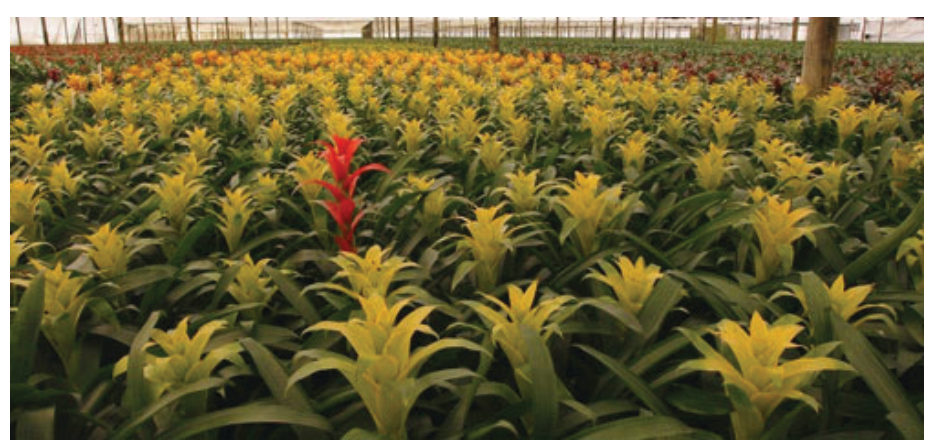

Figure 6. Bromeliads inside a greenhouse, where Wyeomyia vanduzeei can be found outside of its native range of central and southern Florida.

Credits: UF/IFAS

\section{Life Cycle}

\section{Eggs}

Wyeomyia vanduzeei eggs are laid singly and have a waxy coating with fungiform tubercles, small mushroom-shaped structures, on their surface (Frank et al. 1981). The waxy coating acts like a flotation device and increases the buoyancy of eggs in their aquatic habitats. Eggs of other Wyeomyia species that lack a waxy coating sink in waterfilled bromeliad tanks and leaf axils.

\section{Larvae}

Upon hatching from eggs, mosquito larvae are mobile and filter-feed on small particles of organic matter. Despite the presence of organic matter, such as decomposing leaves from the tree canopy, bromeliad tank and leaf axil habitats are typically poor in nutrients. However, compared to other mosquito genera, larval Wyeomyia are resistant to starvation and can delay their development in response to food availability, which aids their survival in nutrient-poor environments (Frank and Curtis 1977). Wyeomyia larvae take at least two weeks to complete development, twice as long as the larval development of other mosquitoes in Florida (Frank 1983). Wyeomyia are the only mosquito larvae found in bromeliads with cream-colored bodies and 
brown intestines that are visible the entire lengths of their bodies (Figure 7; Cutwa and O’Meara 2006).

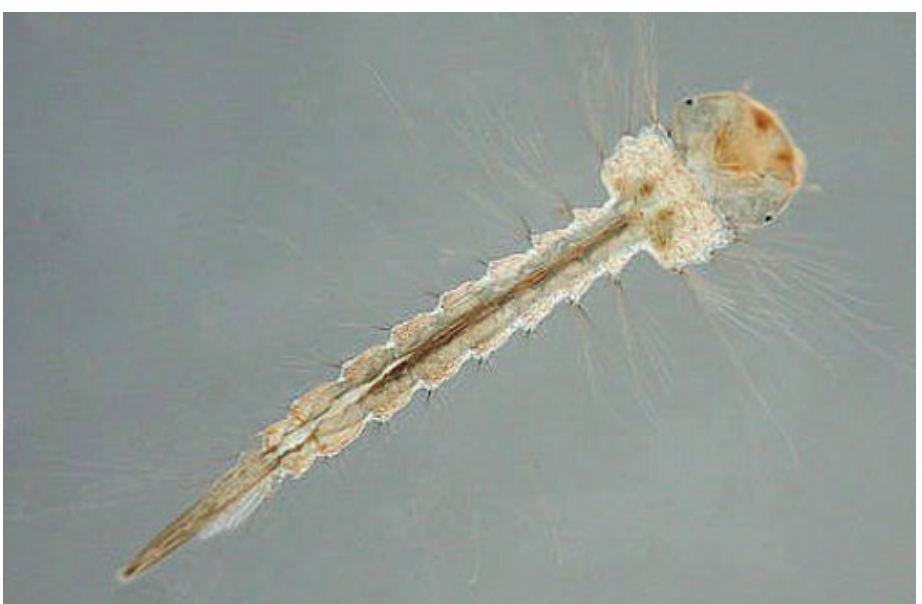

Figure 7. Wyeomyia vanduzeei larva.

Credits: Michele Cutwa (mcutwa@georgiasouthern.edu), Georgia Southern University

In addition to Wyeomyia vanduzeei, the species Wyeomyia mitchelii is also native to Florida and solely. Wyeomyia vanduzeei has three features that distinguishes it from Wyeomyia mitchellii. First the siphon, or breathing tube, protruding dorsally from abdominal segment VIII tends to be longer, with a siphon index (length/width at base) of 6.0 or greater compared to 4.0-5.0 for Wyeomyia mitchellii. Second, each seta or hair on the siphon tends to have two or three branches in Wyeomyia vanduzeei compared to all being single in Wyeomyia mitchellii. Last, seta 4 on abdominal segment X has four branches in Wyeomyia vanduzeei, while the same seta has seven or more branches in Wyeomyia mitchellii (Darsie and Ward 2005).

\section{Pupae}

Wyeomyia vanduzeei larvae enter the pupal stage after their larval development is complete. Although they do not feed in this life stage, pupae are mobile, readily swimming to avoid predation. Pupae take approximately four to five days to finish development, after which adult mosquitoes emerge. Wyeomyia vanduzeei pupae (Figure 8) can be distinguished from Wyeomyia mitchellii pupae by the presence of circular pigmented areas on their second and third abdominal segments (Figure 9).

\section{Adults}

Wyeomyia vanduzeei adults are active during daylight hours and likely to be found in shady areas near bromeliads. Adults are short-lived with limited flight ranges. Females lay eggs singly while in flight above bromeliads (Frank and Curtis 1981). Compared to other adult mosquitoes in Florida, Wyeomyia adults are small and delicate in appearance, often holding their hind legs over their head in a manner that makes them look like an additional pair of antennae (Figure 1). Adult Wyeomyia can be distinguished from other adult mosquitoes by the presence of a line running lengthwise down the sides of their abdomens, separating dark scales on the dorsal (top) portion of the abdomen and light scales on the ventral (underside) portion of the abdomen (Figure 10). The presence of silvery-white scales instead of dark purple or black scales on the antepronotum (Figure 11), a lobed structure located directly behind the head, of adult Wyeomyia vanduzeei distinguishes them from Wyeomyia mitchellii (Cutwa and O’Meara 2006).

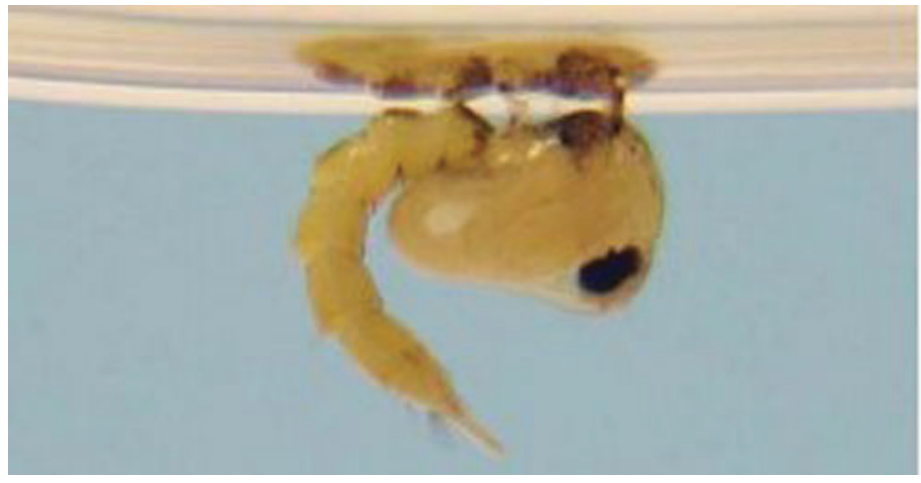

Figure 8. Wyeomyia vanduzeei pupa.

Credits: Michele Cutwa (mcutwa@georgiasouthern.edu), Georgia Southern University

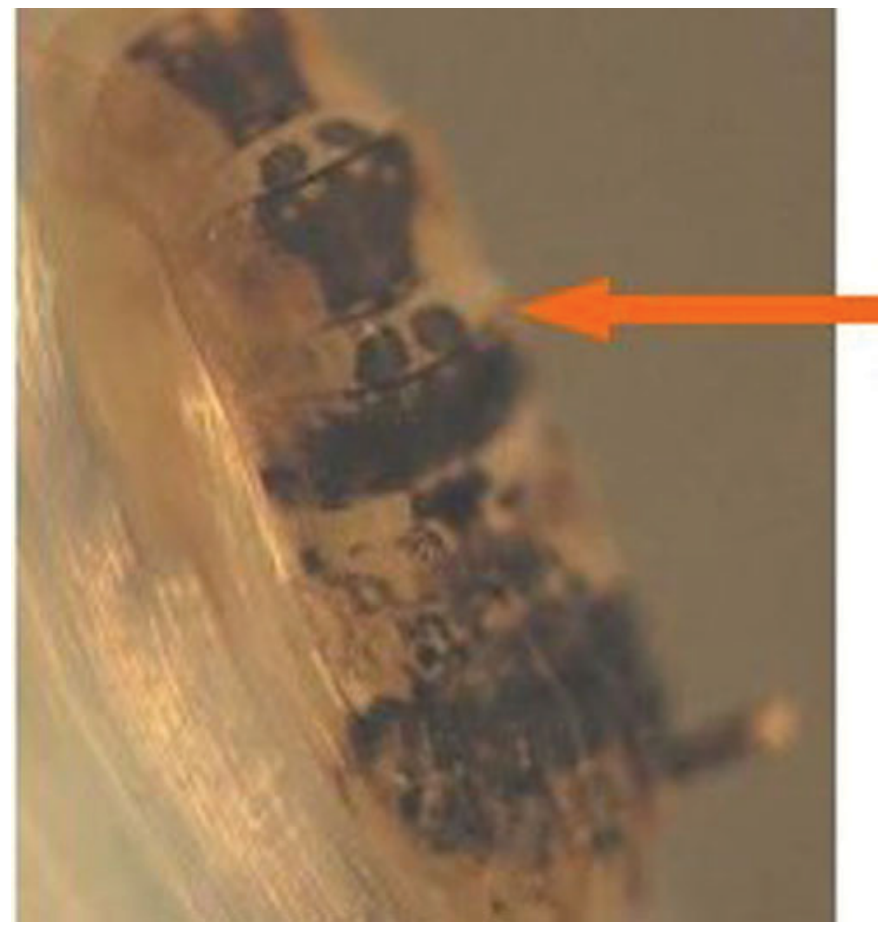

Figure 9. Dorsal view of Wyeomyia vanduzeei pupa with arrow pointing to circular pigmented areas on second abdominal segment. Credits: Michele Cutwa (mcutwa@georgiasouthern.edu), Georgia Southern University 


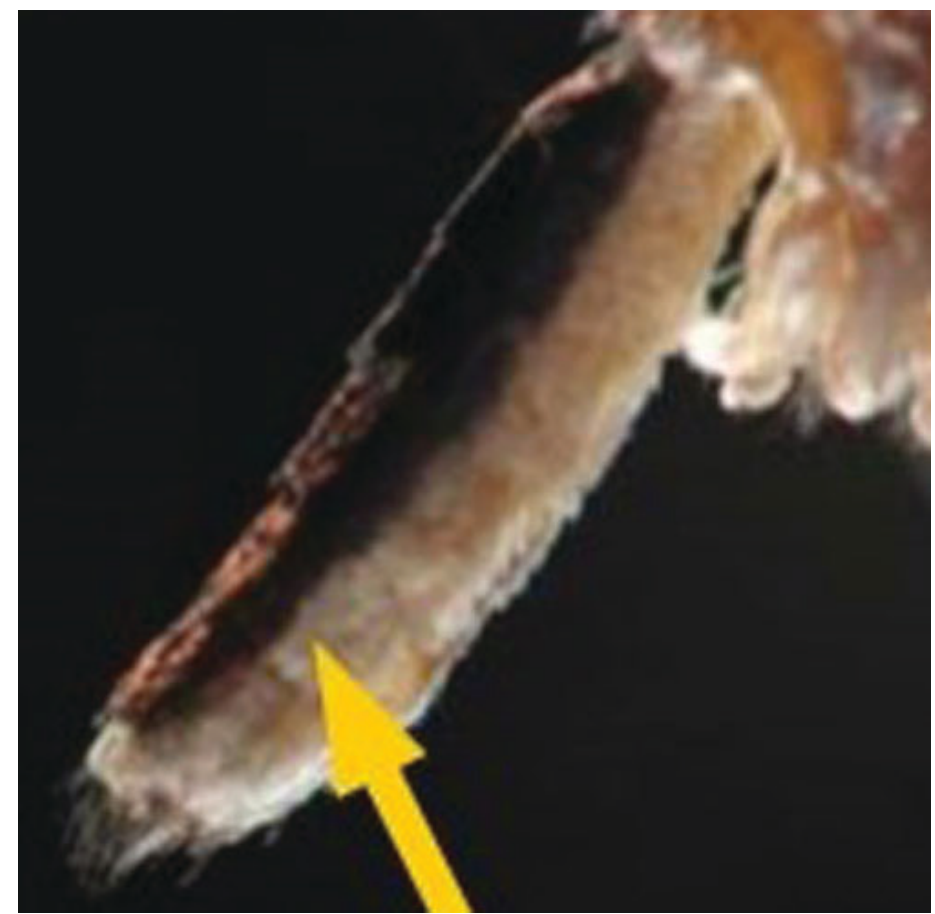

Figure 10. Yellow arrow pointing to the line running lengthwise down the side of the abdomen separating dark scales on the top of the abdomen and light scales on the underside of the abdomen in Wyeomyia mosquitoes.

Credits: Michele Cutwa (mcutwa@georgiasouthern.edu), Georgia Southern University

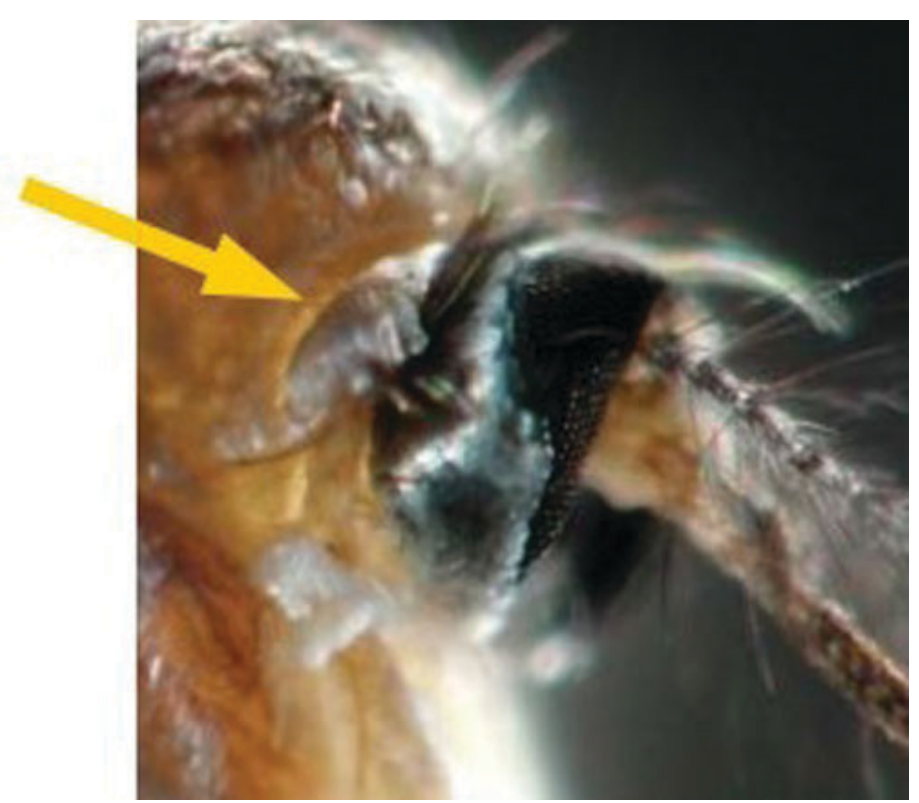

Figure 11. Arrow pointing to the silvery-white scales on the antepronotum, a lobed structure just behind head of adult mosquito, which are distinctive to Wyeomyia vanduzeei.

Credits: Michele Cutwa (mcutwa@georgiasouthern.edu), Georgia Southern University

\section{Medical Importance}

Wyeomyia vanduzeei tends to bite during daylight hours and will take blood meals from humans (Figure 12), causing itching around bites. However, Wyeomyia vanduzeei is not known to transmit viruses that cause diseases in humans and is primarily considered a nuisance species, especially in southern Florida where it can occur yearround (Edman and Haeger 1978).

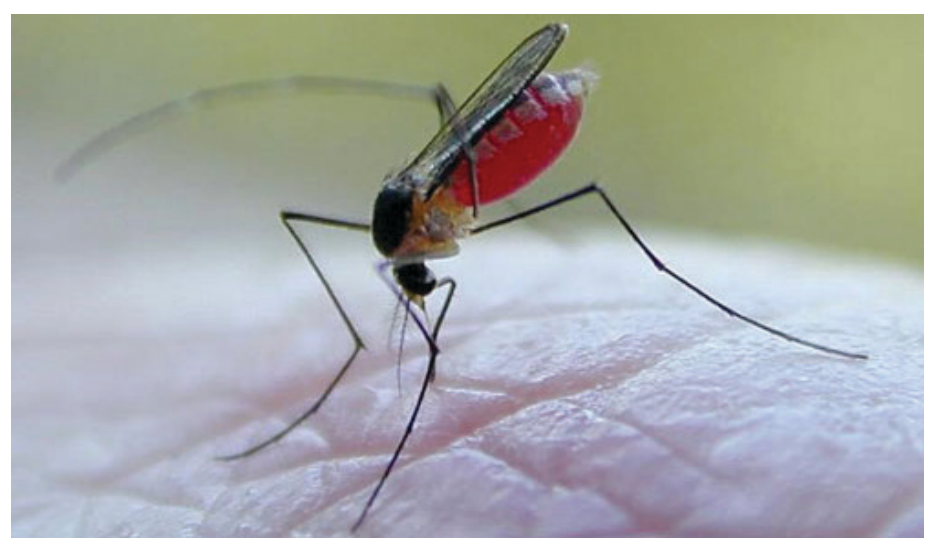

Figure 12. Wyeomyia vanduzeei taking a blood meal from a human. Credits: Jim Newman (newmans@ufl.edu), University of Florida

Although Wyeomyia vanduzeei is not considered to be naturally medically important, the species has been shown to be able to carry viruses, including Tensaw virus and avian pox virus, that can cause diseases in animals other than humans under experimental laboratory conditions (Akey et. al 1981, Nayar et. al 2001).

\section{Surveillance and Management}

Because Wyeomyia vanduzeei generally does not disperse far from bromeliads, the adults usually are only a problem for homeowners and nurseries that grow large numbers of bromeliads. However, the adults may also be a nuisance to neighbors in the immediate area of bromeliad owners and growers.

Bromeliad-inhabiting mosquitoes are sampled by checking the water collected in bromeliads for larvae. Ultra-low volume (ULV) and thermal fog aerosol applications of adulticides are generally not effective at controlling Wyeomyia vanduzeei, as the mosquitoes are active during the day when applications are not advised due to potential negative impacts on other day-active insects, such as bees and butterflies (Curtis and Carlson 1990). Application of a larvicide to bromeliads or regularly flushing plants with water to remove larvae can be effective at reducing bromeliad mosquito populations (Gettman and Frank 1989, Frank 1990). Granular mosquito larvicides may require reapplication every month. However, before use, please consult an insecticide product's label to determine if it is appropriate to use against mosquito larvae and safe for bromeliads. Flushing of bromeliads should take place on a weekly basis. 


\section{Selected References}

Akey BL, Nayar JK, Forrester DJ. 1981. Avian pox in Florida wild turkey: Culex nigripalpus and Wyeomyia vanduzeei as experimental vectors. Journal of Wildlife Diseases 17: 597-599.

Curtis GA, Carlson DB. 1990. Evaluation of hand applied naled thermal fog for Wyeomyia control. Journal of the American Mosquito Control Association 6: 421-424.

Cutwa MM, O’Meara GF. 2006. Photographic guide to common mosquitoes of Florida. University of Florida, Florida Medical Entomology Laboratory 1:1-83.

Edman JD, Haeger JS. 1978. Host-feeding patterns of Florida mosquitoes V. Wyeomyia. Journal of Medical Entomology 14: 477-479.

Frank JH, Curtis GA. 1977. On the bionomics of bromeliad-inhabiting mosquitoes. III. The probable strategy of larval feeding in Wyeomyia vanduzeei and Wy. medioalbipes. Mosquito News 37: 200-206.

Frank JH, Curtis GA. 1981. Bionomics of the bromeliadinhabiting mosquito Wyeomyia vanduzeei and its nursery plant Tillandsia utriculata. Florida Entomologist 64: 491-507.

Frank JH, Curtis GA, Erdos GW, Ellis EA. 1981. On the bionomics of bromeliad-inhabiting mosquitoes. VIII. The flotational structure of Wyeomyia vanduzeei eggs (Diptera: Culicidae). Journal of Medical Entomology 18: 337-340.

Frank JH, Lynn HC, Goff JM. 1985. Diurnal oviposition by Wyeomyia mitchelli and W. vanduzeei (Diptera: Culicidae). The Florida Entomologist 68: 493-496.

Frank JH, Stewart JP, Watson DA. 1988. Mosquito larvae in axils of the bromeliad Billbergia pyramidalis in southern Florida. The Florida Entomologist 71: 33-43.

Frank JH. 1990. Bromeliads and mosquitoes. Entomology Circular No. 331. Florida Department of Agriculture and Consumer Services.

Frank JH, Fish D. 2008. Potential biodiversity loss in Florida bromeliad phytotelmata due to Metamasius callizona (Coleoptera: Dryophthoridae), an invasive species. Florida Entomologist 91:1-8.
Gettman AD, Frank JH. 1989. A method to reduce Wyeomyia mitchellii eggs in Billbergia pyramidalis bromeliads. Journal of the Florida Anti-Mosquito Association 60: 7-8.

Nayar JK, Karabatsos N, Knight JW, Godsey M, Chang J, Mitchell CJ. 2001. Mosquito hosts of arboviruses from Indian River County, Florida, during 1998. Florida Entomologist 84: 376-379.

O’Meara GF, Cutwa MM, Evans LF. 2003. Bromeliadinhabiting mosquitoes in South Florida: Native and exotic plants differ in species composition. Journal of Vector Ecology 28: 37-46. 